\title{
A comparative quality study and energy saving on intermittent heat pump drying of
}

Malaysian edible bird's nest

\begin{abstract}
This paper aims to study the influence of temperature and relative humidity $(\mathrm{RH})$ during intermittent heat pump drying at $28.6-40.6^{\circ} \mathrm{C}, 16.2-26.7 \% \mathrm{RH}, \alpha=0.2-1.0$, and the comparison was made against fan drying $\left(27^{\circ} \mathrm{C}, 39.7 \% \mathrm{RH}, \alpha=1.00\right)$. It was observed that the effects of temperature and $\mathrm{RH}$ on drying rate were significant when moisture content was high. Experimental results showed that intermittent heat pump drying at $28.6^{\circ} \mathrm{C}, 26.7 \% \mathrm{RH}$, $\alpha=0.2$ of edible bird's nest greatly reduced effective drying time by $84.2 \%$ and color change compared to fan drying, and retained the good energy efficiency.
\end{abstract}

Keyword: Color change; Edible bird's nest; Energy saving; Fan drying; Intermittent heat pump drying; Nitrite content 